\title{
PERBAIKAN SIFAT FUNGSIONAL TEKNIS TEPUNG BIJI KELOR (MORINGA OLEIFERA) DENGAN PERKECAMBAHAN
}

\author{
[Improvement of the Technical Functional Properties of Moringa Oleifera \\ Seed flour By Germination]
}

\author{
Candytias Puspitasari, Sukarno*, dan Slamet Budijanto \\ Departemen Ilmu dan Teknologi Pangan, Fakultas Teknologi Pertanian, Institut Pertanian Bogor, Bogor
}

Diterima 8 Mei 2019 / Disetujui 28 November 2019

\begin{abstract}
Germination constitutes one of bio-processing techniques and has attracted a tremendous attention due to its advantageous effects on the improvement of technical functional properties of grains. Meanwhile, blanching has been used as the complementary treatment in gemination. The aim of this study was to evaluate the changes in the functional properties of Moringa oleifera seed flour due to gemination and blanching that affect the characteristics of the resulting food the products. Germination was performed at four levels of incubation time $(0,48,72$, and 96 hours) at room temperature in the dark room and two levels of blanching time ( 0 and 30 second). The functional properties analyzed consisted of bulk density, flour solubility, water and oil absomtion, and capacity and stability of emulsion. The results of this study showed that germinated Moringa seed flour had significantly better technical functional characteristics than the ungeminated ones, i.e. bulk density (0.33-0.43 g/mL), flour solubility (16.82-21.00 g/g), water absomtion capacity (0.93-0.99 g water/g), oil absorption capacity $(1.18-1.58 \mathrm{~mL}$ oil/g), and emulsion capacity (88.80-91.70\%). Blanching decreased the functional properties of the flour. The statistical analysis showed that there was no significant interaction between two factors in all parameters. This study shows that germination is a good method to improve the functional properties of Moringa seed flour, but blanching decreases them. Germination without blanching is recommended to improve the technical functional characteristics of the flour.
\end{abstract}

Keywords: blanching, germination, moringa oleifera, technical functional properties

\begin{abstract}
ABSTRAK
Perkecambahan merupakan salah satu metode yang menarik perhatian karena dilaporkan mampu memperbaiki sifat fungsional teknis pada biji-bijian. Metode blansir juga digunakan sebagai perlakuan komplemen dari perkecambahan. Penelitian ini bertujuan mempelajari pengaruh perlakuan perkecambah an dan blansir terhadap sifat fungsional teknis tepung kecambah biji kelor yang berpenganh pada karakteristik produk pangan. Perkecambahan dilakukan pada 4 level waktu inkubasi yang berbeda $(0,48,72$, dan 96 jam) pada ruang gelap, sedangkan waktu blansir dilakukan pada 2 level waktu yang berbeda ( 0 dan 30 detik). Parameter yang diamati meliputi densitas kamba, kelanutan, daya serap air dan minyak, serta kapasitas dan stabilitas emulsi. Hasil penelitian menunjukkan bahwa tepung kecambah biji kelor memiliki karakteristik fungsional teknis seperti densitas kamba $(0,33-0,43 \mathrm{~g} / \mathrm{mL})$, kelanutan $(16,82-21,00 \mathrm{~g} / \mathrm{g})$, daya serap air (0,93-0,99 g air/g), dan minyak (1,18-1,58 mL minyak/g) serta kapasitas emulsi $(88,80$ $91,7 \%$ ) yang lebih baik daripada tepung yang tidak dikecambahkan. Blansir menurunkan kemampuan atau karak-teristik yang dimiliki oleh tepung. Analis is statistik menunjukkan tidak terdapat interaksi antara kedua faktor pada seluruh parameter uji. Berdasarkan hasil analisis dapat disimpulkan bahwa perkecambahan dapat memperbaiki sifat fungsional teknis tepung biji kelor, sedangkan blansir memberikan efek menurunkan ke-mampuan atau karakteristik yang dimiliki tepung biji kelor. Tepung kecambah tanpa blansir merupakan perlakuan yang direkomendasikan untuk memperbaiki karakteristik tepung yang dihasilkan.
\end{abstract}

Kata kunci: biji kelor, blansir, perkecambahan, sifatfungsional teknis tepung

*Penulis Korespondensi:

E-mail: dsukarno@apps.ipb.ac.id 


\section{PENDAHULUAN}

Kelor (Moringa oleifera) merupakan tamanan yang berasal dari barat laut India dan banyak tumbuh di daerah beriklim tropis maupun subtropis seperti India, Sri Lanka, Malaysia, Filipina, dan Indonesia. Kelor telah dikenal sebagai sumber pangan bergizi tinggi dan berpotensi untuk dimanfaatkan sebagai salah satu pangan alternatif untuk mengatasi masalah malnutrisi. Aminah et al. (2015) melaporkan bahwa setiap bagian dari tanaman kelor dapat dimanfaatkan. Beberapa bagian digunakan sebagai pangan karena memiliki nilai gizi yang tinggi dan lainnya dimanfaatkan sebagai obat karena kandungan senyawa bioaktif pada tanaman kelor bermanfaat untuk kesehatan. Oleh sebab itu, tanaman ini sering disebut sebagai the miracle tree karena keberagaman manfaat yang ditawarkan.

Biji kelor merupakan bagian dari tanaman kelor yang memiliki kandungan protein paling tinggi dibandingkan dengan bagian lainnya, yaitu mencapai 31,4 $\mathrm{g} / 100 \mathrm{~g}$ berat kering (Leone et al., 2016). Barakat dan Ghazal (2016) melaporkan bahwa biji kelor mengandung asam amino es ensial yang cukup lengkap dengan leusin sebagai komposisi tertingginya yang berkisar antara 2.080-2.299 mg/100 g. Hal ini menunjukkan bahwa biji kelor merupakan sumber protein nabati yang cukup potensial dan dapat dimanfaatkan sebagai pangan alternatif untuk memenuhi asupan protein dan asam amino esensial di dalam tubuh. Hal tersebut juga didukung oleh ketersediaan biji kelor yang cukup melimpah, setiap pohon dari tanaman kelor dapat memproduksi sekitar 25.000 biji/tahun (Krisnadi, 2015). Tanaman ini dapat tumbuh dengan cepat dan memiliki kemampuan beradaptasi yang tinggi pada berbagai kondisi lingkungan sehingga mudah untuk dibudidayakan (Teixeira et al., 2014). Beberapa daerah di Indonesia juga telah banyak membudidayakan tanaman kelor ini karena potensinya yang cukup tinggi.

Kegunaan biji kelor sebagai pangan belum banyak diketahui, umumnya biji kelor yang masih muda dikonsumsi sebagai sayur. Pemanfaatan biji kelor dalam industri pangan dapat diolah, salah satunya menjadi tepung karena lebih mudah diaplikasikan dalam berbagai pangan olahan. Saat ini informasi tentang karakteristik tepung biji kelor belum banyak dilaporkan, sehingga perlu dilakukan penelitian lebih lanjut. Karakteristik tepung seperti daya serap air dan minyak, densitas kamba, dan kapasitas emulsi yang baik sangat penting untuk mengoptimalkan pemanfaatannya. Metode perkecambahan merupakan salah satu inovasi yang dapat digunakan untuk memperbaiki sifat-sifat fungsional teknis pada bahan pangan (Elkhalifa dan Bernhardt, 2010). Sifat fungsional teknis adalah sifat terkait fungsi dalam mencapai sifat-sifat mutu produk seperti emulsifikasi, pengembangan volume, dan lain-lain tanpa melibat- kan efek fungsional untuk kesehatan. Perkecambahan cukup mudah untuk dilakukan dan tidak mahal, selain itu metode ini sering digunakan untuk meningkatkan nilai gizi dan menurunkan senyawa antigizi yang sering ditemukan pada biji-bijian (Donkor et al., 2012; Warle et al., 2015). Aplikasi perkecambahan pada biji kelor ini diharapkan mampu memperbaiki karakteristik pada tepung yang dihasilkan sehingga pemanfaatannya dapat digunakan secara lebih luas dalam pangan olahan. Sebagai perlakuan komplemen dilakukan blansir. Metode ini sering digunakan untuk menurunkan antigizi seperti asam fitat dan inhibitor tripsin pada kedelai dan black bean (Trugo et al., 2000). Biji kelor diketahui mengandung senyawa asam fitat sebesar $0,59 \mathrm{mg} / \mathrm{g}$ (Abiodun et al., 2012). Namun, pengaruh blansir terhadap karakteristik fungsional teknis tepung biji kelor belum banyak dilaporkan. Oleh sebab itu, pengujian sifat fungsional teknis pada biji kelor dengan perlakuan perkecambahan dan blansir perlu untuk dilakukan. Sifat fungsinal teknis tepung berperan dalam pengolahan pangan, penyimpanan, pengendalian mutu pangan, dan penerimaannya oleh konsumen seperti aroma, rasa, tekstur, warna, penampakan, dan cita rasa. Sutedja (2010) menyatakan bahwa pemilihan jenis dan pola pemanfaatan yang dilakukan dalam industri pengolahan pangan harus disesuaikan dengan karakteristik dari bahan pangan tersebut, sehingga diharapkan dengan perlakuan perkecambahan dan blansir pada biji kelor dapat memperoleh hasil yang optimal, yaitu karakteristik tepung yang lebih baik dan pemanfaatannya dalam industri pangan dapat digunakan secara lebih luas. Penelitian ini bertujuan untuk mengkaji pengaruh perkecambahan dan blansir terhadap perbaikan sifat fungsional teknis tepung biji kelor. Hasil penelitian ini diharapkan mampu mendukung pemanfaatan dan meningkatkan nilai tambah dari sumber lokal Indonesia, yaitu biji kelor dalam industri pangan.

\section{BAHAN DAN METODE}

\section{Bahan}

Bahan utama yang digunakan pada penelitian ini adalah biji kelor yang sudah matang berwarna cokelat kehitaman. Biji kelor diperoleh dari UD. Agro Sejahtera Kota Kediri, Jawa Timur dan digunakan beberapa bahan lain seperti minyak jagung, $\mathrm{NaOH}$ 2N (Merck, Jerman) serta akuades untuk proses analisis.

\section{Perlakuan biji kelor (Pandilla et al., 2012; Chinma et al., 2013)}

Proses perkecambahan diawali dengan tahap pembersihan, yaitu penghilangan selaput putih (exotesta) pada kulit luar biji kelor, kemudian dicuci dan direndam pada suhu $\pm 30^{\circ} \mathrm{C}$ selama 24 jam 
menggunakan air dingin (Padilla el al., 2012). Perendaman dilakukan untuk menyediakan kondisi lingkungan yang dibutuhkan untuk perkecambahan. Biji dikecambahkan pada berbagai level lama waktu inkubasi yaitu selama 0 (kontrol perlakuan), 48, 72, dan 96 jam. Biji diletakkan dalam wadah berlubang pada bagian bawahnya dan diinkubasi dalam ruang gelap pada suhu ruang $\left( \pm 30^{\circ} \mathrm{C}\right)$. Selama inkubasi setiap 4 jam sekali biji disiram dengan air yang bertujuan untuk memfasilitasi proses perkecambahan. Metode perkecambahan biji kelor mengikuti metode Chinma et al. (2013). Proses dilanjutkan dengan tahap blansir dalam air mendidih dengan perbandingan $(1: 8 \mathrm{~b} / \mathrm{v})$. Waktu proses blansir terdiri atas 2 level, yaitu 0 (kontrol perlakuan) dan 30 detik, sehingga diperoleh dua macam biji kelor, yaitu biji kecambah tanpa blansir (TB) dan biji kecambah dengan blansir. Tahapan selanjutnya adalah proses penepungan yang terdiri dari beberapa tahap antara lain pengeringan, penggilingan, dan pengayakan. Pengeringan kecambah biji kelor dilakukan pada suhu $50^{\circ} \mathrm{C}$ dalam oven (Cascade Tek Oven Experts, USA) selama 24 jam. Kecambah biji kelor yang kering kemudian diproduksi menjadi tepung menggunakan pin disc mill ayakan 60 mesh dan dikemas pada kantong plastik dan aluminium foil kemudian disimpan dalam lemari pendingin $\left(4^{\circ} \mathrm{C}\right)$. Gambar 1 menunjukkan penampakan biji kelor sebelum dan sesudah perkecambahan dan blansir.

\section{Analisis sampel}

Perlakuan pembuatan tepung kecambah kelor dilakukan sebanyak dua kali ulangan dan masingmasing dianalisis dengan dua kali pengukuran (duplo) pada setiap perlakuan. Karakteris asi tepung yang dilakukan adalah densitas kamba yang dinyatakan sebagai perbandingan berat sampel terhadap volumenya $(\mathrm{g} / \mathrm{mL})$ (Astawan et al., 2016), kelarutan tepung (g/g) (Fajri et al., 2016), daya serap air yang dihitung sebagai perbandingan antara berat sampel akhir setelah di oven dan berat sampel awal ( $\mathrm{g}$ air/g) (Khattab dan Arnfield, 2009), daya serap minyak (mL minnyak/g) (Khattab dan Arnfield, 2009), kapasitas emulsi (\%) yang dinyatakan sebagai perbandingan volume campuran yang teremulsi (setelah pengocokan) dan volume campuran sebelum dikocok dengan hand blender (Philips HR 1603, Indonesia), sedangkan stabilitas emulsi diukur dengan mengamati perubahan emulsi yang terjadi tiap 15 menit (Ghavidel dan Prakash, 2006).

\section{Rancangan percobaan dan pengolahan data}

Penelitian ini menggunakan rancangan percobaan acak lengkap faktorial (RALF) dengan 2 faktor percobaan yaitu lama perkecambahan (0, 48, 72, dan 96 jam) dan blansir (0 dan 30 detik). Data yang diperoleh diolah menggunakan program komputer microsoft excel, kemudian dilakukan analisis ragam
(ANOVA) two way pada taraf signifikasi $5 \%$ untuk beda nyata. Beda nyata antar masing-masing sampel kemudian dianalisis dengan uji Duncan menggunakan program IBM SPSS® version 22.

\section{HASIL DAN PEMBAHASAN}

\section{Densitas kamba}

Densitas kamba menyatakan suatu keringkas an bahan dalam menempati volume. Nilai densitas kamba yang semakin tinggi menunjukkan bahwa bahan tersebut memiliki keringkasan yang semakin besar, karena dalam volume yang sama tepung memiliki berat yang lebih besar. Densitas kamba ini penting dalam hal pengemasan dan penyimpanan. Berdasarkan analisis ANOVA menunjukkan bahwa tidak terdapat interaksi yang signifikan $(P<0,05)$ antara kedua faktor terhadap densitas kamba tepung biji kelor, namun perkecambahan dan blansir masingmasing berpengaruh signifikan $(P<0,05)$ terhadap peningkatan densitas kamba tepung. Berdasarkan Tabel1menunjukkan bahwa densitas kamba tepung biji kelor berkisar antara 0,33-0,43 g/mL. Densitas kamba tepung biji kelor ini memiliki nilai yang relatif rendah jika dibandingkan dengan beberapa tepung lain yang berkisar antara 0,55-0,85 g/mL seperti tepung beras (Chinma et al., 2015), cowpea, green gram, lentil, bengal gram (Ghavidel dan Prakash, 2006), tepung sorgum (Elkhalifa dan Bernhardt, 2010), tepung komposit okra dan terigu (Akoja dan Coker, 2018), dan tepung terigu (Chandra et al., 2015). Tepung biji kelor memiliki densitas kamba yang relatif rendah. Hal ini dapat disebabkan oleh ukuran partikel tepung biji kelor yang lebih besar akibat proses pengayakan saat penepungan.

Tepung biji kelor yang dikecambahkan memiliki densitas kamba yang lebih tinggi daripada tepung yang tidak dikecambahkan. Astawan et al. (2016) menjelaskan bahwa selama proses perkecambahan akan memicu aktivitas enzim proteolitik untuk menghidrolisis senyawa-senyawa kompleks menjadi bentuk yang lebih sederhana, sehingga ukuran partikel menjadi lebih kecil dan densitas kamba tepung meningkat. Peningkatan densitas kamba akibat proses perkecambahan juga terjadi pada tepung beras (Moongngarm et al., 2014). Tepung kecambah biji kelor dengan perlakuan blansir (B) memiliki densitas kamba yang sedikit lebih tinggi daripada tepung tanpa blansir (TB). Hal ini mungkin dipengaruhi oleh kadar air tepung (Efendi et al., 2015). Tepung kecambah biji kelor dengan blansir (B) memiliki kadar air yang lebih tinggi $(4,79-6,18 \%$ bk) daripada tanpa blansir (TB) $(4,67-6,04 \%$ bk), dengan demikian berat tepung dengan perlakuan blansir menghasilkan nilai yang lebih besar dibandingkan tepung tanpa blansir (TB). Hal tersebut berdampak pada pengukuran densitas kamba tepung. 


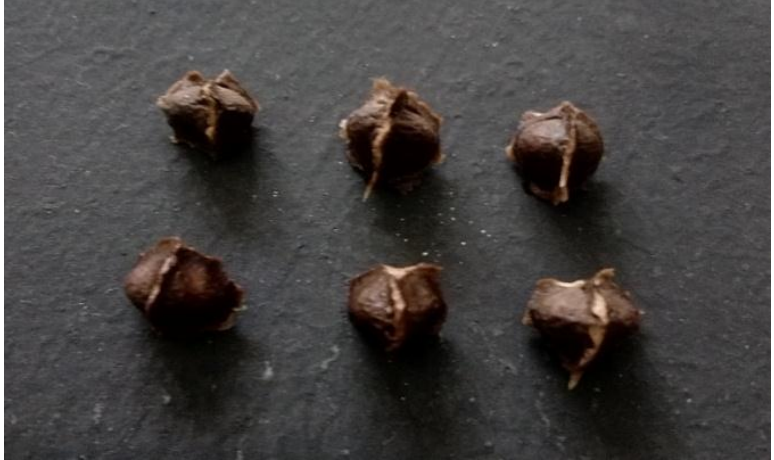

A

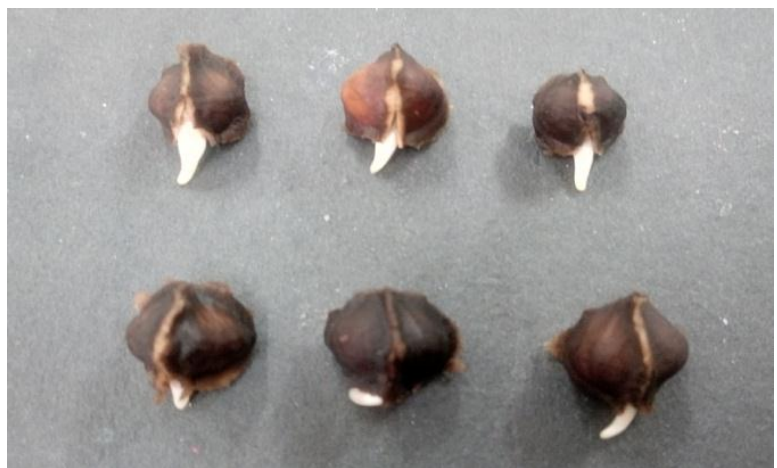

C

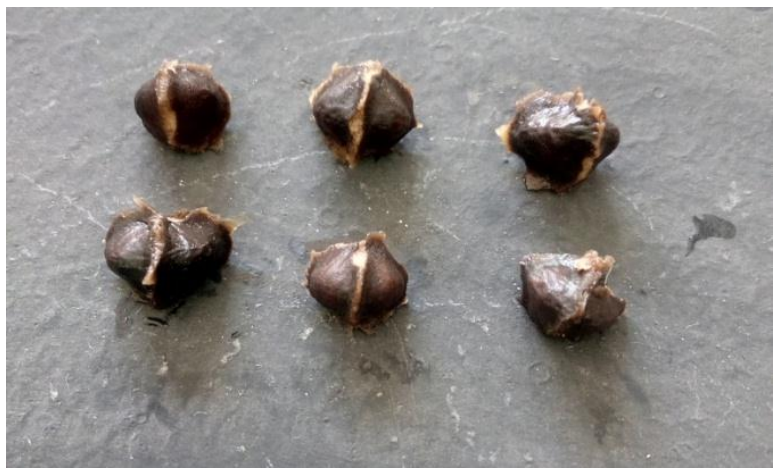

E

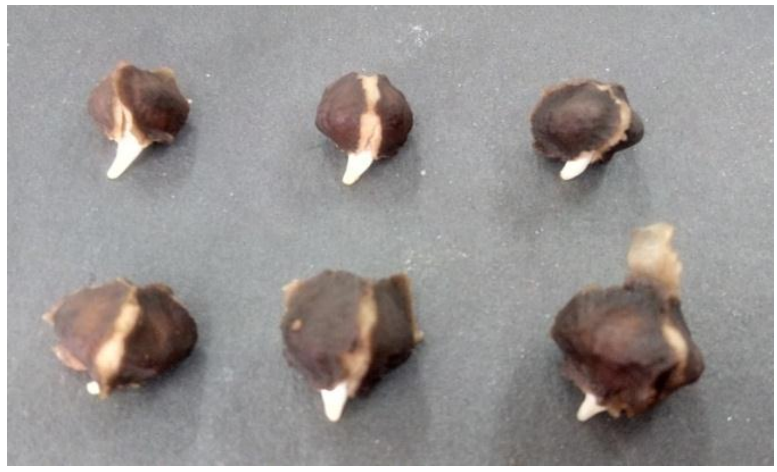

G

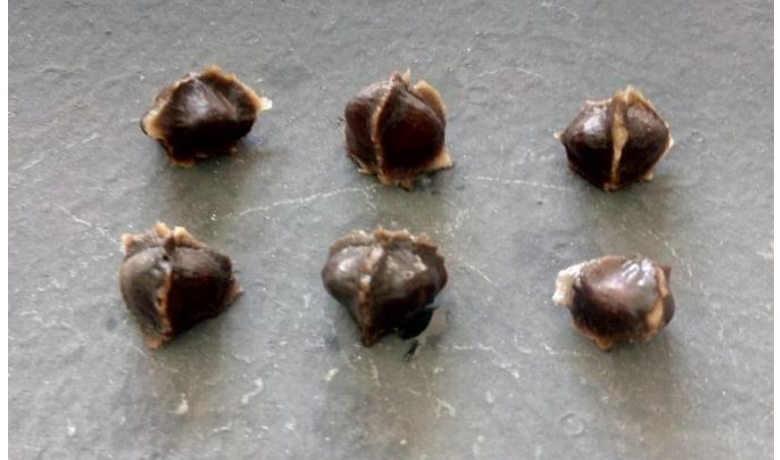

B

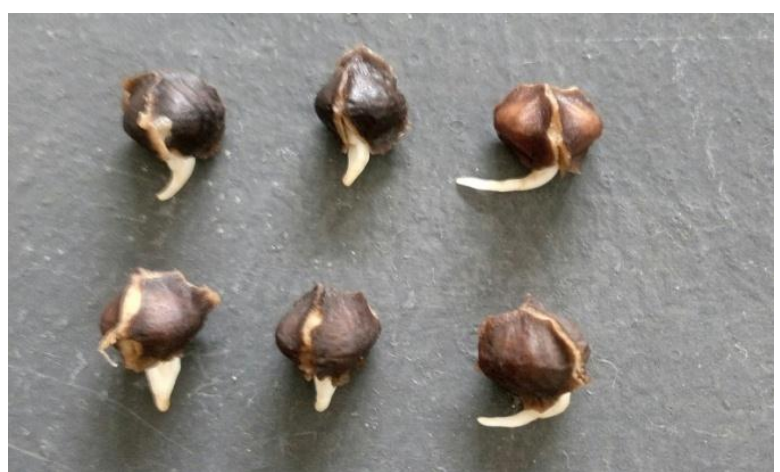

D

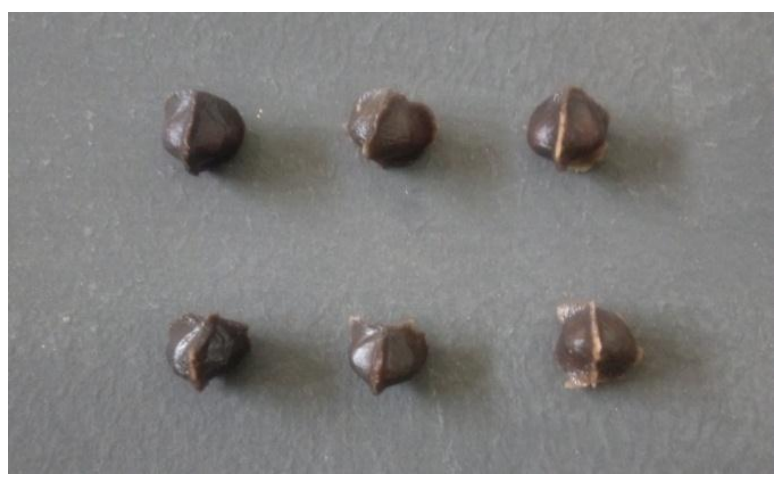

$\mathbf{F}$

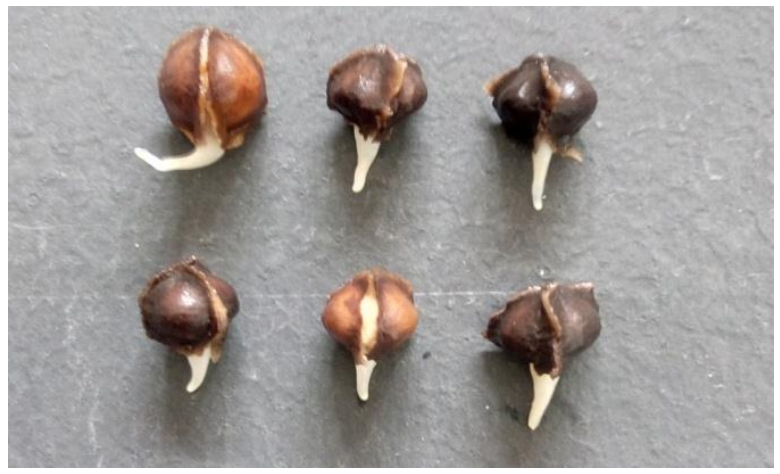

$\mathbf{H}$

Keterangan: $A=T B$ 0, $B=T B$ 48, $C=T B$ 72, $D=T B$ 96, $E=B$ 0, $F=B$ 48, G=B 72, H= B 96, TB= Kecambah tanpa blansir; $B=$ Kecambah dengan blansir

Gambar 1. Penampakan biji kelor sebelum dan setelah dikecambahkan dan blansir 
Tabel 1. Pengaruh perkecambahan dan blansir terhadap sifat fungsional tepung biji kelor

\begin{tabular}{lcccccccc}
\hline \multirow{2}{*}{ Pengamatan } & \multicolumn{7}{c}{ Lama Perkecambahan (Jam) } \\
\cline { 2 - 9 } & \multicolumn{2}{c}{0} & \multicolumn{7}{c}{48} & \multicolumn{3}{c}{72} & TB & B & TB \\
\cline { 2 - 8 } & TB & B & TB & B & B \\
\hline Densitas kamba & $0,33 \pm$ & $0,34 \pm$ & $0,35 \pm$ & $0,35 \pm$ & $0,41 \pm$ & $0,42 \pm$ & $0,42 \pm$ & $0,43 \pm$ \\
(g/mL) & 0,00 & 0,02 & 0,00 & 0,01 & 0,00 & 0,00 & 0,00 & 0,01 \\
Kelarutan (g/g) & $17,43 \pm$ & $16,82 \pm$ & $21,00 \pm$ & $20,37 \pm$ & $20,41 \pm$ & $20,09 \pm$ & $19,18 \pm$ & $18,63 \pm$ \\
& 1,45 & 0,29 & 0,25 & 0,11 & 0,59 & 0,10 & 0,44 & 1,58 \\
Daya serap air (g & $0,94 \pm$ & $0,93 \pm$ & $0,96 \pm$ & $0,95 \pm$ & $0,98 \pm$ & $0,97 \pm$ & $0,99 \pm$ & $0,98 \pm$ \\
air/g) & 0,00 & 0,00 & 0,00 & 0,00 & 0,01 & 0,01 & 0,01 & 0,00 \\
Daya serap minyak & $1,52 \pm$ & $1,18 \pm$ & $1,53 \pm$ & $1,18 \pm$ & $1,58 \pm$ & $1,29 \pm$ & $1,58 \pm$ & $1,43 \pm$ \\
(mL minyak/g) & 0,08 & 0,01 & 0,07 & 0,01 & 0,01 & 0,00 & 0,01 & 0,07 \\
Kapasitas emulsi (\%) & $90,00 \pm$ & $88,80 \pm$ & $91,40 \pm$ & $89,20 \pm$ & $91,70 \pm$ & $90,10 \pm$ & $91,70 \pm$ & $89,90 \pm$ \\
& 0,00 & 0,28 & 0,00 & 0,28 & 0,14 & 0,42 & 0,42 & 0,14 \\
\hline
\end{tabular}

Keterangan: $\mathrm{TB}=$ Kecambah tanpa blansir; $\mathrm{B}=$ kecambah dengan blansir; Berdasarkan analisis statistik tidak terdapat interaksi signifikan antara kedua faktor, masing-masing perlakuan tidak berbeda nyata pada $(P<0,05)$

\section{Kelarutan tepung}

Kelarutan menyatakan tingkat kemudahan tepung untuk larut di dalam air, semakin besar nilai kelarutan maka semakin tinggi daya larut bahan tersebut di dalam air. Berdasarkan analisis statistik, tidak terdapat interaksi pada kedua faktor pada taraf signifikansi $(P<0,05)$, namun perkecambahan memberikan pengaruh yang signifikan, tepung yang dikecambahkan memiliki kelarutan yang lebih besar daripada tepung yang tidak dikecambahkan. Hal serupa juga dilaporkan oleh Wisaniyasa et al. (2015), yang menyebutkan bahwa perkecambahan dapat memperbaiki sifat kelarutan dari tepung. Selama proses perkecambahan terjadi proses hidrolisis oleh enzim proteolitik dan amilase, senyawa makromolekul seperti protein dan karbohidrat dipecah menjadi senyawa yang lebih sederhana yang mengakibatkan peningkatan kemampuan tepung untuk larut dalam air.

Berdasarkan Tabel 1 diketahui bahwa kelarutan tepung kecambah biji kelor berkisar antara 16,82$21,00 \mathrm{~g} / \mathrm{g}$. Nilai tersebut hampir sama dengan tepung pigeon pea yang dikecambahkan selama 4872 jam (Wisaniyasa et al., 2015), namun lebih rendah dibandingkan tepung lain seperti tepung bengkuang (Dewi et al., 2012). Pada Tabel 1 terlihat bahwa kelarutan tepung biji kelor tertinggi adalah pada jam ke 48 perkecambahan, yaitu sebesar $21,00 \mathrm{~g} / \mathrm{g}$ (bk) (TB) dan 20,37 g/g (bk) (B), dan menurun pada jam ke 72 dan 96. Hal tersebut dapat dijelaskan bahwa pada jam ke 48 terjadi aktivitas hidrolisis karbohidrat dan protein menjadi gula sederhana dan asam amino. Gula sederhana memiliki gugus polihidroksil yang dapat mengikat air melalui ikatan hidrogen yang mengakibatkan tepung tersebut mudah Iarut. Asam amino seperti serin, treonin, prolin, asparagin, dan glutamin memiliki gugus hidroksil, fenol, dan amida yang dapat berikatan dengan air membentuk ikatan hidrogen (Kusnandar, 2010). Kelarutan tepung biji kelor pada jam ke 72 dan 96 menurun, namun penurunan tersebut tidak signifikan.

\section{Daya serap air}

Hasil analisis statistik menunjukkan bahwa tidak terdapat interaksi yang signifikan $(P<0,05)$ antara kedua faktor, namun lama perkecambahan dan blansir masing-masing berpengaruh signifikan $(P<0,05)$ terhadap peningkatan daya serap air. Peningkatan daya serap air akibat perkecambahan juga ditunjukkan pada beberapa tepung, seperti tepung beras (Chinma et al., 2015), pigeon pea (Wisaniyasa et al., 2015), lentil, horsegram (Ghumman et al., 2016), sorgum (Elkhalifa dan Bernhardt, 2010), dan jagung (Adedeji et al., 2014). Daya serap air yang lebih tinggi pada tepung yang dikecambahkan dapat disebabkan oleh komposisi asam amino, diduga asam amino polar dan ionik pada tepung kecambah biji kelor lebih banyak sehingga meningkatkan kemampuan daya serap airnya (Astawan dan Hazmi, 2016). Selain itu proses hidrolisis karbohidrat selama perkecambahan meningkatkan interaksi antara gugus polar untuk berikatan dengan air sedangkan daya serap air pada tepung kecambah biji kelor dengan perlakuan blansir (B) memiliki kemampuan yang lebih rendah dari perlakuan tanpa blansir (TB). Kusnandar (2010) menjelaskan bahwa pemanasan akan menurunkan jumlah air yang terikat, hal ini disebabkan terjadinya denaturasi protein akibat panas. Penggunaan bahan dengan daya serap air yang tinggi dapat memperbaiki kualitas tekstur dan mouthfeel pada pangan yang dihasilkan serta memperbaiki kualitas produk daging (Astawan dan Hazmi, 2016; Köhn et al., 2015).

Daya serap air tepung biji kelor yang tidak dikecambahkan dan dikecambahkan berkisar antara 0,93-0,99 g air/g seperti yang ditunjukkan pada Tabel 1. Nilai tersebut sama dengan daya serap air tepung komposit sorgum-terigu (20:80), yaitu $0,93 \mathrm{~g}$ air/g (Adebowale et al., 2012). Namun, nilai ini masih lebih rendah jika dibandingkan tepung kedelai dan tepung komposit sukun-terigu yang memiliki daya serap air sebesar 2,24 $\mathrm{g}$ air/g dan 1,05-1,55 g air/g (Astawan dan Hazmi, 2016; Aderinola, 2016). Astawan dan Hazmi (2016) menjelaskan bahwa per- 
bedaan kemampuan tepung dalam mengikat air ini dipengaruhi oleh kemampuan protein yang dapat mengikat air karena memiliki gugus hidrofilik. Zayas (1997) menyatakan bahwa daya serap air tergantung dari komposisi asam amino pada suatu bahan. Selain itu keberadaan serat pangan pada bahan memiliki gugus hidrofilik yang bersifat polar dan berinteraksi dengan air melalui ikatan hidrogen, sehingga juga memengaruhi daya serap air.

\section{Daya serap minyak}

Daya serap minyak merupakan kemampuan suatu bahan untuk berinteraksi dengan minyak dan penting karena dapat bertindak dalam memperkuat flavor dan mouthfeel (Ghavidel dan Prakash, 2006). Hasil uji statistik menunjukkan bahwa tidak terdapat interaksi antara kedua faktor namun masing-masing faktor memberikan pengaruh signifikan $(P<0,05)$ terhadap daya serap minyak. Tabel 1 menunjukkan bahwa terdapat peningkatan daya serap minyak pada tepung tanpa blansir (TB) dan diblansir (B) selama proses perkecambahan. Peningkatan daya serap minyak selama proses perkecambahan juga terjadi pada tepung sorgum (Elkhalifa dan Bernhardt, 2010), tepung pigeon pea (Wisaniyasa et al., 2015), green gram, kacang tunggak, lentil, dan bengal gram (Ghavidel and Prakash, 2006). Chinma et al. (2015) menjelaskan bahwa selama perkecambahan terjadi aktivitas hidrolisis protein yang menyebabkan pemutusan ikatan dari sebagian polipeptida, sehing ga sisi hidrofobik dari asam amino pada rantai peptida dapat berikatan dengan minyak/lemak.

Daya serap minyak tepung biji kelor berkisar antara 1,18-1,58 mL minyak/g. Daya serap minyak tepung biji kelor ini hampir sama dengan tepung buck wheat dan konsentrat isolat kedelai yang berkisar antara 1,33-1,54 mL minyak/g (Baljeet et al., 2010; Astawan dan Hazmi, 2016), namun lebih rendah dari tepung dan isolat okara (Sutedja, 2010). Zayas (1997) menjelaskan bahwa penyerapan minyak oleh tepung dapat terjadi karena komposisi protein dalam tepung ters ebut. Protein selain memiliki gugus hidrofilik juga memiliki rantai samping hidrofobik yang bersifat non polar, pada sisi tersebut terjadi interaksi antara protein dan minyak. Selain itu keberadaan lemak pada tepung biji kelor juga cukup tinggi $(24,04-36,71 \%)$ bk, sehingga juga memengaruhi kemampuan daya serap minyaknya. Hasil penelitian juga menunjukkan bahwa tepung tanpa blansir (TB) memiliki daya serap minyak yang lebih tinggi dibandingkan tepung yang diblansir (B), hal ini dapat terjadi karena proses blansir menyebabkan terjadinya denaturasi protein yang menyebabkan penurunan kemampuan daya serap minyak. Bahan pangan yang memiliki daya serap minyak yang tinggi penting dalam produk daging seperti sosis, pancake, dan sup.

\section{Kapasitas dan stabilitas emulsi}

Kapasitas emulsi berhubungan dengan kemam puan protein dalam menurunkan tegangan permukaan antara dua komponen pada bahan pangan, yaitu hidrofobik dan hidrofilik. Analisis statistik menunjukkan bahwa tidak terdapat interaksi signifikan, namun lama perkecambahan dan blansir berpengaruh signifikan $(P<0,05)$ terhadap kapasitas emulsi yang dihasilkan. Pada Tabel 1 terlihat peningkatan kapasitas emulsi seiring dengan lama waktu perkecambahan, hal serupa juga terjadi pada tepung sorgum (Elkhalifa dan Bernhardt, 2010), green gram, kacang tunggak, lentil, bengal gram (Ghavidel dan Prakash, 2006), dan jagung (Adedeji et al., 2014). Pada penelitian ini diketahui bahwa kapasitas emulsi tepung kecambah $(0,48,72$, dan 96 jam) berkisar antara $88,80-91,70 \%$. Kapasitas emulsi tepung biji kelor ini lebih tinggi jika dibandingkan dengan isolat protein kecipir (70,5\%) (Budijanto et al., 2011), tepung terigu $(43,88 \%)$ (Chandra et al., 2015) dan amaranthus (24,63-31,17\%) (Adeniyi dan Obatolu, 2014). Perkecambahan dapat menyebabkan terjadinya disasosiasi dan terbukanya struktur parsial polipeptida sehing ga sisi hidrofobik polipeptida menjadi terpapar ke lingkungan. Hal ini dapat membantu pengikatan antara sisi hidrofobik dengan droplet lemak. Proses ini dapat memperluas area permukaan protein dan meningkatkan kapasitas emulsinya (Elkhalifa dan Bernhardt, 2010). Perlakuan blansir menyebabkan terjadinya penurunan kapasitas emulsi, hal ini seperti yang telah dilaporkan oleh Sutedja (2010) bahwa pemanasan dapat menurunkan kapasitas dan stabilitas emulsi. Pemanasan dengan suhu tinggi dapat menyebabkan denaturasi total protein sehingga kemampuannya dalam mengemulsi juga menurun.

Stabilitas emulsi menggambarkan kualitas emulsi yang terbentuk. Pengukuran stabilitas emulsi dilakukan dengan mengamati banyaknya air yang terpisah dari emulsi. Air yang terpisah dari emulsi berada pada sisi bagian bawah. Selama waktu 2,5 jam pengamatan terlihat stabilitas emulsi yang cukup beragam, pada Gambar 2 diketahui bahwa tepung tanpa blansir (TB) memiliki stabilitas yang lebih baik dibandingkan dengan tepung yang mendapat perlakuan blansir (B). Kusnandar (2010) menjelaskan bahwa peningkatan ukuran droplet akibat koalesen dapat meny ebabkan ketidakstabilan suatu emulsi. Informasi tersebut menunjukkan bahwa tepung kecambah biji kelor tanpa blansir (TB) memiliki kapasitas emulsi yang cukup tinggi sehingga baik digunakan pada produk olahan daging seperti sosis dan bakso yang membutuhkan sifat kemampuan emulsifikasi yang stabil dalam pembentukan emulsi lemak (Budijanto et al., 2011). 


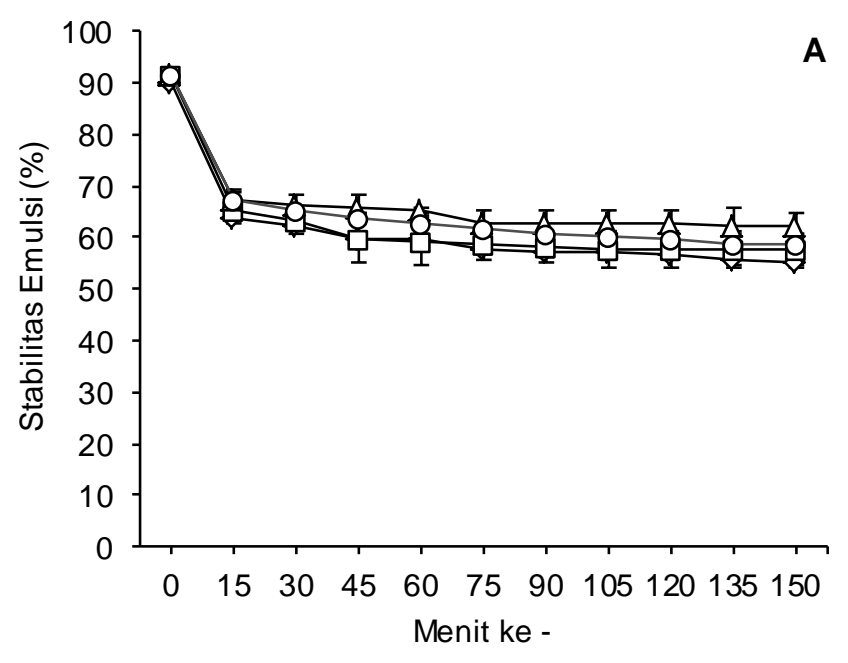

$\curvearrowright$ TB $0 \multimap \square$ TB $48 \backsim$ TB $72 \multimap$ - TB 96

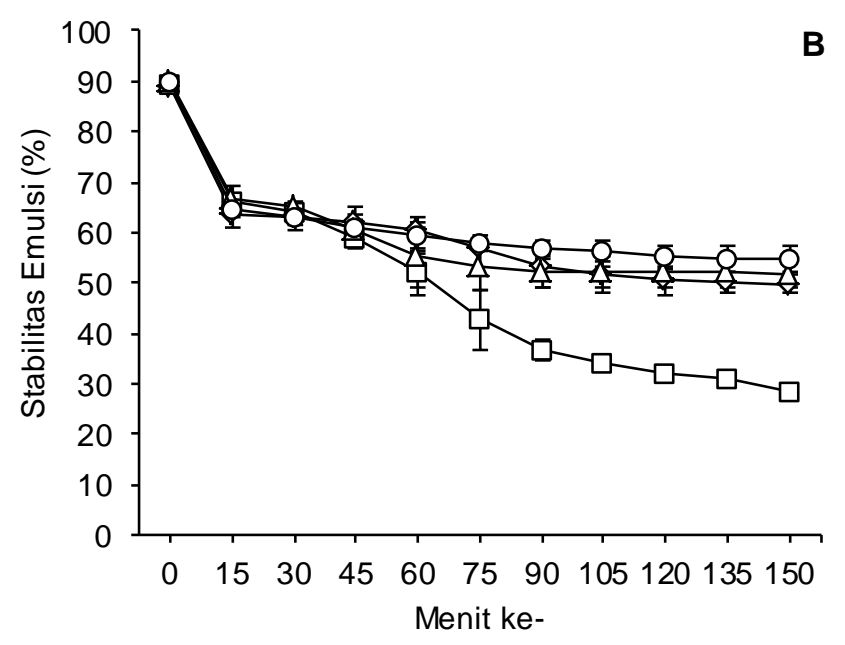

$\hookleftarrow$ B $0 \multimap$ В $48 \neg$ В $72 \multimap$ В 96

Gambar 2. Stabilitas emulsi tepung kecambah biji kelor tanpa blansir (A) dan dengan blansir (B)

\section{KESIMPULAN}

Proses perkecambahan selama 96 jam mampu memperbaiki fungsional tepung yang meliputi, densitas kamba $(0,43 \mathrm{~g} / \mathrm{mL})$, daya serap air $(0,99 \mathrm{~g}$ air $/ \mathrm{g})$, daya serap minyak (1,58 mL minyak/g), dan kapasitas emulsi $(91,70 \%)$. Perlakuan blansir berpengaruh terhadap penurunan karakteristik tepung yang dihasilkan seperti daya serap air, daya serap minyak, dan kapasitas emulsi, namun meningkatkan densitas kamba. Pada semua parameter tidak terdapat interaksi yang signifikan antara kedua faktor (perke- cambahan dan blansir). Tepung kecambah tanpa blansir (TB) merupakan perlakuan yang direkomendasikan untuk memperbaiki sifat fungsional tepung.

\section{UCAPAN TERIMAKASIH}

Penulis mengucapkan terimakasih yang sebesar-besarnya kepada Lembaga Pengelola Dana Penelitian (LPDP). LPDP telah mendanai penelitian ini sehingga penelitian ini dapat diselesaikan dengan baik.

\section{DAFTAR PUSTAKA}

Abiodun OA, Adegbite JA, Omolola AO. 2012. Chemical and physicochemical properties of moringa flours and oil. Global J Sci Front Res 12: 13-18.

Adebowale AA, Adegoke MT, Sanni SA, Adegunwa MO, Fetuga GO. 2012. Functional properties and biscuit making potentials of sorghum -wheat flour composite. Am J Food Technol 7: 372379. DOI: 10.3923/ajtt.2012.372.379.

Adedeji OE, Oyinloye OD, Ocheme OB. 2014. Effects of germination time on the functional properties of maize flour and the degree of gelatinization of its cookies. Afr J Food Sci 8: 4247. DOI: $10.5897 / A J F S 2013.1106$.

Adeniyi PO, Obatolu VA. 2014. Effect of germination temperature on the functional properties of grain amaranthus. Am J Food Sci Technol 2: 76-79. DOI: 10.12691/ajfst-2-2-5.

Aderinola TA. 2016. Effects of processing techniques on the functional properties of wheatbreadfruit composite flour. Int Food Res J 23: 2759-2762.

Akoja SS, Coker OJ. 2018. Physicochemical, functional, pasting and sensory properties of wheat flour biscuit incorporated with ok ra powder. Int $\mathrm{J}$ Food Sci Nutr 3: 64-70.

Aminah S, Ramdhan T, Yanis M. 2015. Kandungan nutrisi dan sifat fungsional tanaman kelor (Moringa oleifera). Buletin Pertanian Perkotaan 5: 35-44.

Astawan M, Hazmi K. 2016. Karakteristik fisiko kimia tepung kecambah kedelai. J Pangan 25: 105112.

Astawan M, Wresdiati T, Ichsan M. 2016. Karakteristik fisikokimia tepung tempe kecambah kedelai. J Gizi Pangan 11: 35-42. 
Baljeet SY, Ritika BY, Roshan LY. 2010. Studies on functional properties and incorporation of buckwheat flour for biscuit making. Int Food Res $\mathrm{J}$ 17: 1067-1076.

Barakat H, Ghazal GA. 2016. Physicochemical properties of Moringa oleifera seeds and their edible oil cultivated at different region in Egypt. Food Nutr Sci 7: 472-484. DOI: 10.4236/fns. 2016.76049.

Budijanto S, Sitanggang AZ, Murdiati W. 2011. Karakterisasi sifat fisiko-kimia dan fungsional isolat protein biji kecipir (Psophocarpus tetragonolobus L.). J Teknol Industri Pangan 12: 130 136.

Chandra S, Singh S, Kumari D. 2015. Evaluation of functional properties of composite flour and sensorial attributes of composite flour biscuits. J Food Sci Technol 52: 3681-3688. DOI: 10.100 7/s13197-014-1427-2.

Chinma CE, Gbadamosi KB, Ogunsina BS, Oloyede OO, Salami SO. 2013. Effect of addition of germinated moringa seed flour on the quality atributes of wheat-based cake. J Food Process Pres 38: 1737-1742. DOI: 10.1111/jfpp. 12136.

Chinma CE, Anuonye JC, Simon OC, Ohiare RO, Danbada N. 2015. Effect of germination on the physicochemical and antioxidant characteristics of rice flour from three rice varieties from Nigeria. Food Chem 185: 454-458. DOI: 10.101 6/j.foodchem.2015.04.010.

Dewi NS, Prananto NHR, Ridwan A. 2012.Karakteristik sifat fisiko kimia tepung bengkuang ( $\mathrm{Pa}$ chyrhizuserosus) dimodifikasi secara asetilasi dengan variasi konsentrasi, asam asetat selama perendaman. J Teknol Hasil Pertanian 5: 104-112. DOI: 10.20961/jthp.vi0.13014.

Donkor ON, Stojanovska L, Ashton J,Vasiljevic T. 2012.Germinated grains-Sources of bioactive compounds. Food Chem 135: 950-959. DOI: 10.1016/j.foodchem.2012.05.058.

Efendi Z, Surawan FED, Winarto. 2015.Efek blanching dan metode pengeringan terhadap sifat fisiko kimia tepung ubi jalar orange (Ipomoea batatas L.). J Agroind 5: 109-117. DOI: 10.3118 6/j.agroind.5.2.109-117.

Elkhalifa AEO, Bernhardt R. 2010. Influence of grain germination on functional properties of sorghum flour. Food Chem 121: 387-392. DOl: 10.1016/j. foodchem.2009.12.041.

Fajri F, Tamrin, Asyik DN. 2016. Pengaruh modifikasi HMT (Heat Moisture Treatment) terhadap si- fat fisikokimia dan nilai organoleptik tepung sagu (Metroxylon sp.). J Sains Teknologi Pangan 1: $37-44$

Ghavidel RA, Prakash J. 2006. Effect of germination and dehulling on functional properties of legume flours. J Sci Food Agr 86: 1189-1195. DOI: 10.1002/jsfa.2460.

Ghumman A, Kaur A, Singh N. 2016. Impact of germination flour, protein, and starch characteris tics of lentil (Lens culinary) and horsegram (Macrotyloma uniflorum L.) lines. LWT-Food Sci Technol 65: 137-144. DOI: 10.1016/j.Iwt.2015.0 7.075.

Khattab RY, Arntfield SD. 2009. Fuctional properties of raw and processed canola meal. LWT-Food Sci Technol 42: 1119-1124. DOI: 10.1016/j.Iwt. 2009.02.009.

Köhn CR, Fontoura AM, Kempka AP, Demiate IM, Kubota EH, Prestes RC. 2015. Assessment of different methods for determining the capacity of water absorption of ingredient and additives used in the meat industry. Int Food Res J 22: 356-362.

Krisnadi AD. 2015. Kelor Super Nutrisi. 12-13. Ebook, Blora.

Kusnandar F. 2010. Kimia Pangan Komponen Makro. 238-244. Dian Rakyat, Jakarta.

Leone A, Spada A, Battezzati A, Schiraldi A, Aristil J, Bertoli S. 2016. Moringa oleifera seeds and oil: Charecteristics and uses for human health. Int J Mol Sci 17: 1-14. DOI: 10.3390/ijms17122 141.

Moongngarm A, Moontree T, Deedpinrum P, Padtong K. 2014. Functional properties of brown rice flour as affected by germination. APCBEE Proc 8: 41-46. DOI: 10.1016/j.apcbee.2014.01. 077.

Padilla C, Fraga N, Suárez M. 2012. Effect of the soaking time of moringa (Moringa oleifera) seeds on the germination and growth indicator of the plant. Cuban J Agr Sci 46: 419-421.

Sutedja AM. 2010. Fraksinasi Protein dan Karakterisasi Sifat Fungsional Tepung Okara [Tesis]. Bogor: Fakultas Teknologi Pertanian, Institut Pertanian Bogor.

Teixeira EMB, Carvalho MRB, Neves VA, Silva MA, Arantes-Pereira L. 2014. Chemical characteristics and fractination of proteins from Moringa oleifera Lam. leaves. Food Chem 147: 51-54. DOI: 10.1016/j.foodchem.2013.09.135. 
Trugo LC, Donangelo CM, Trugo NMF, Knudsen KEB. 2000. Effect of heat treatment on nutritional quality of germinated legumes seeds. J Agr Food Chem 48: 2082-2086. DOI: 10.1021/jf991 3920.

Warle BM, Riar CS, Gaikwad SS, Mane VA. 2015. Effect of germination on nutritional quality of soybean (Glycine Max). International Organiza- tion of Science Research (IOSR)-J Environ, Toxicol Food Technol 9: 13-16.

Wisaniyasa NW, Suter K, Marsono Y, Putra IK. 2015. Germination effect on functional properties and antitrypsin activities of pigeon pea (Cajanus can (L.) Mill sp.) sprout flour. Food Sci Qual Manage 43: 79-84.

Zayas JF. 1997. Fuctionality of Protein in Food. 79228. Springer, Berlin. 